\title{
Monthly and Seasonal Variation in the Amount of Total Lipid and Fatty Acid in the Muscle of a Silurid Cat Fish Wallagu attu
}

\author{
PINAK DUTTA $^{1 *}$ and MITA DUTTA ${ }^{2}$ \\ 'Department of Chemistry, Bejoy Narayan Mahavidyalaya, Itachuna, Hooghly - 712147, India. \\ ${ }^{2}$ Department of Chemistry, Sreegopal Banerjee College, Bagati, Magra, Hooghly - 712148, India. \\ ${ }^{*}$ Corresponding author E-mail: pimidu@ yahoo.com \\ http://dx.doi.org/10.13005/ojc/300351
}

(Received: June 06, 2014; Accepted: July 08, 2014)

\begin{abstract}
Monthly and seasonal variation in the amount of total lipid and fatty acid in the muscle tissues of $W$. attu growing wild in large ponds was studied. The result depicts that both the amounts of total lipid and fatty acid varied monthly and thus seasonally in this fish species (boal) belonging to the family of fresh water silurid cat fishes. The percentage of total lipid value reaches its minimum in May and starts increasing from June to October. During breeding season the amount of total fatty acid also shows the same tendency to decrease till May when it reaches its minimum. From June onwards the total fatty acid increases significantly. At the end of the reproductive season, i.e. during the commencement of the nutritional season, the fishes start the process of storing energy in the form of lipids / fatty acids for future use i.e. during reproduction season or during scarcity of food. This is what is reflected in the study that, during the monsoon months in West Bengal the lipid / fatty acid content in the muscle tissues of boal rises to the maximum. This starts decreasing in the winter season as the reproduction period approaches and reaches its minimum in summer.
\end{abstract}

Key words: Wallagu attu, muscle tissues, lipid, fatty acid, seasonal variation, monthly variation.

\section{INTRODUCTION}

Now-a-days the names like PUFA, DHA, EPA, $\Omega$-3-fatty acids are so much and so frequently used that a scientific mind is bound to get attracted to it. Systematic studies have revealed that these names are directly linked to human health and nutrition. Furthermore, DHA, EPA also has disease curative properties. ${ }^{1-11}$ Polyunsaturated fatty acids are something that a body cannot make and needs to obtain it from daily diet. The best possible source of such polyunsaturated fatty acid is fish be it of salt water or fresh water. An article in Circulation ${ }^{12}$ (Journal of the American Heart Association) opined that eating oily fish at least twice a week may help prevent sudden death from heart attack, as fatty 
acids in the fish block dangerous heart rhythms. Studies of individual heart cells showed that the fatty acids blocked excessive sodium and calcium currents in the heart, which could otherwise cause dangerous unpredictable changes in its rhythm. French researchers concluded that, people who ate fish at least once a week had a far lower risk of being diagnosed with dementia. ${ }^{13}$ Harvard medical school and Brigham Women's Hospital in the USA found that a diet rich in oily fish raised the bodies' production of an anti-inflammatory fat, thus possibly reducing the effects of arthritis. ${ }^{14}$ Edinburgh and Stirling Universities in connection with Edinburgh Royal Hospital for sick children, suggested that oily fish could help deal with the effects of childhood autism. Such is the utility of the consumption of unsaturated fatty acids and the best and source of such acids is fish oil. So, tremendous work is going on throughout the world to detect and preserve fish species (both salt and fresh water) rich in such unsaturated fatty acids. ${ }^{15-19}$

India and specially West Bengal is well known for her huge resources of fresh water fishes apart from those obtained from salt water. In India this huge fish resource has not been properly utilized for human and animal consumption till now, although attempts have been undertaken in this field in different laboratories. With the increase in population, food for all and that too nutritious and cheap is becoming a major concern for developing countries (like India). Thus farmed fish is gradually becoming the main contributor to India's nutrition supplement. So it is becoming important to keep a vigil on the type of fishes farmed, their feed, and their growing conditions. Keeping this in mind, we have taken up one of the largest, voracious predator among the fresh water cat fishes growing wild in West Bengal Wallagu attu (Boal) for investigation. Very little is known about this fish's lipid / fatty acid content. ${ }^{17}$ Thus we have taken up the project of studying this fish's monthly as well as seasonal variation of lipid concentration as well as its fatty acid percentage.

Wallagu attu (Boal) is an important fresh water fish of the silurid cat-fish family found and consumed in West Bengal, India. Boal, as is locally known, is one of the largest, voracious and destructive among the fresh water cat fishes found in rivers, tanks and large ponds. ${ }^{20}$ Little is known about the proximate composition, lipid content and fatty acid percentage of such a fish consumed well in rural Bengal. To conclude about this fish's nutritive value, we have studied both the monthly as well as seasonal variations in the amount of total lipid and fatty acids in its muscle tissues. Such studies of seasonal and monthly variation of lipid, fatty acid content in different fish species are in its infancy ${ }^{21}$ and much work is required in this field to gain valuable knowledge regarding their proper rearing and systematic farming.

\section{MATERIALS AND METHODS}

Three fish samples were caught from the same pond near Punduah, West Bengal, India between $5^{\text {th }}$ to $15^{\text {th }}$ day of every month. The time interval was rigidly maintained so that the comparative studies could be done. The average weights for these fishes were about $(1150 \pm 11.25)$ gms. Fishes were killed by hitting on the heads and brought to the laboratory. Samples were stored at $-30{ }^{\circ} \mathrm{C}$ in a freezer until they were used. ${ }^{22}$ After measuring the total length and weight of the fishes their proximate composition were analyzed. ${ }^{23}$ The edible portions (the muscle tissues of the body) were separated from the head, skin, bone and viscera. The body muscles removed from the bones and cut into small pieces. They were then put in a clean blender, which had been sterilized before hand, and minced for 30 seconds. About $40 \mathrm{ml}$ of $0.25 \%$ acetic acid was added to the minced pieces and they were minced again for 30 seconds to get a dough like homogenous mixture. ${ }^{24} 20 \mathrm{gms}$ of the minced pieces were used for extraction of the total lipids with a chloroform : methanol mixture considering the advices of Folch et. al. ${ }^{25}$ After extraction the crude total lipid was purified, dried and weighed by using the same method of Folch. ${ }^{25}$ The total lipids were saponified, and the unsaponified portions were discarded. The saponified part was acidified by adding $6(\mathrm{M})$ hydrochloric acid until it reached $\mathrm{pH}$ 1. Thus the total fatty acids obtained were dried and weighed. All weights were recorded in $\mathrm{mg}$ in a 0.0001 gm sensitive balance. Total fatty acid percentage was also found by means of the total lipid. Monthly average values were obtained from these data. Therefore, a comparison was made between the months. 


\section{RESULT AND DISCUSSIONS}

The amount of total lipid obtained from the muscle of $W$. attu during generation period (February to May, being a pre-monsoon breeder), shows a tendency to decrease. The value reaches its minimum in May and again starts increasing from June to October. During breeding season the amount of total fatty acid also shows the same tendency to decrease till May when it reaches its minimum. From June onwards the total fatty acid increases significantly. Thus one can conclude that both the total lipid content and total fatty acid content of $W$. attu varies throughout the year (table 1). This is quite natural as the storage of lipids, fatty acids in different organs and tissues in a fish are the results of irregular seasonal variations and water temperature, which affect the fish diet. ${ }^{26-31}$

Reproduction and nutritional physiology are the two most important biological properties associated in the total life span of a fish. ${ }^{32-35}$ So, proper storage and utilization of lipids and fatty acids in various organs and tissues vary according to the biological need of a fish. For instance, during reproduction season, the lipid stored in various organs and tissues should be mobilized to the gonads for the development of the gonads. ${ }^{36}$ So, the lipid/fatty acid content in the organs/muscle tissues should decrease. Our study also reflects the same trend of decrease in both the lipid as well as the fatty acid content in the muscle tissues of $W$. attu in the months of February, March, April (table 1) as boal is a pre-monsoon breeder. Thus during the summer season, the total lipid percentage and total fatty acid percentage in the muscle tissues of $W$. attu is the minimum (table 2).

At the end of the reproductive season, i.e. during the commencement of the nutritional season, the fishes start the process of storing energy in the form of lipids / fatty acids for future use i.e. during reproduction season or during scarcity of food. This is what is reflected in our study that, during the

Table 1: The monthly variation of total lipid and fatty acid in muscle tissue of Boal (Wallagu attu)

\begin{tabular}{lccc}
\hline Month & $\begin{array}{c}\text { Total Lipid } \\
\%\end{array}$ & $\begin{array}{c}\text { Total Fatty acid } \\
\%\end{array}$ & $\begin{array}{c}\text { Approximate Total Fatty acid \% } \\
\text { with respect to Total Lipid \% }\end{array}$ \\
\hline January & $6.23 \pm 0.01$ & $4.31 \pm 0.03$ & $69.23 \pm 0.35$ \\
February & $4.39 \pm 0.01$ & $2.87 \pm 0.02$ & $65.30 \pm 0.31$ \\
March & $3.32 \pm 0.01$ & $1.91 \pm 0.02$ & $57.43 \pm 0.80$ \\
April & $3.02 \pm 0.02$ & $1.62 \pm 0.01$ & $53.64 \pm 0.03$ \\
May & $2.91 \pm 0.02$ & $2.25 \pm 0.01$ & $77.35 \pm 0.36$ \\
June & $3.28 \pm 0.02$ & $2.59 \pm 0.01$ & $79.02 \pm 0.02$ \\
July & $6.65 \pm 0.01$ & $5.06 \pm 0.02$ & $75.87 \pm 0.26$ \\
August & $6.84 \pm 0.03$ & $5.14 \pm 0.02$ & $76.49 \pm 0.33$ \\
September & $7.22 \pm 0.02$ & $5.53 \pm 0.02$ & $82.44 \pm 0.39$ \\
October & $7.13 \pm 0.02$ & $5.87 \pm 0.01$ & $76.57 \pm 0.22$ \\
November & $6.16 \pm 0.02$ & $4.74 \pm 0.02$ & $71.26 \pm 0.51$ \\
December & $6.74 \pm 0.02$ & $4.80 \pm 0.02$ & \\
\hline
\end{tabular}

Table 2: The seasonal variation of total lipid and fatty acid in muscle tissue of Boal (Wallagu attu)

\begin{tabular}{lccc}
\hline Month & $\begin{array}{c}\text { Total Lipid } \\
\%\end{array}$ & $\begin{array}{c}\text { Total Fatty acid } \\
\%\end{array}$ & $\begin{array}{c}\text { Approximate Total Fatty acid \% } \\
\text { with respect to Total Lipid } \%\end{array}$ \\
\hline Winter & $5.89 \pm 0.03$ & $3.70 \pm 0.04$ & $62.82 \pm 0.41$ \\
Summer & $3.14 \pm 0.01$ & $2.39 \pm 0.03$ & $76.12 \pm 0.30$ \\
Monsoon & $6.98 \pm 0.03$ & $5.04 \pm 0.05$ & $72.21 \pm 0.15$ \\
\hline
\end{tabular}


monsoon months in West Bengal the lipid / fatty acid content in the muscle tissues of boal rises to the maximum. This starts decreasing in the winter season as the reproduction period approaches and reaches its minimum in summer (table 2 ).

\section{CONCLUSION}

The data obtained is quite justified and thus should bring about consciousness amongst us in preserving this fish species. Secondly, the concentration of both the total lipid and total fatty acids present in a fish depends on its feeding habit which again depends on the food sources present in the reservoir where the fish thrives. Thus the study definitely gives an insight on the types of food required as well as the environmental conditions required for proper farming of such fish species $(W$. attu). The new information's obtained will definitely contribute to future projects in this discipline.

\section{REFERENCES}

1. Simopoulos; Artemis. Am. J. Clinical Nutrition 1991, 54, 438-463.

2. Pepping; Joseph. Am. J. Health-System Pharmacy 1999, 56, 719-720.

3. Connor, William E. Am. J. Clinical Nutrition 2000, 71 (suppl), 171S-175S.

4. Laugharne, J.D.E. et. al. Lipids 1996, 31 (suppl), S163-S165.

5. Jensen, Craig L., et. al. Am. J. of Clinical Nutrition 2000, 71 (suppl), 292S-299S.

6. Makrides; Maria; Gibson; Robert A. Am. J. Clinical Nutrition 2000, 71 (suppl), 307S-311S.

7. Montano, N.; Gavina, G.; Gavino, V. C. Food Chem. 2001, 75, 611-614.

8. Sanderson, P.; Finnegan, Y. E.; Williams, C. M.; Calder, P. C.; Burdge, G. C.; Wootton, S. A.; Griffin, B. A.; Millward, D. J.; Pegge, N. C.; Bemelmans, W. J. E. Br. J. Nutr. 2002, 88, 573-579.

9. Calder, P. C. Nutr. Res. 2004, 24, 761-772.

10. Harris, W. S. Int. Congr. Ser. 2004, 1262, 380383.

11. Givens, D. I.; Kliem K. E.; Gibbs R. A. Meat Sc. 2006, 74, 209-218.

12. Leaf, A.; Kang, J.X.; Xiao, Y.; Billman, G. Circulation 2003, 107, 2646-2652.

13. Emma Wilkinson (2009-03-09). "Health I Oily fish dementia boosts queried". BBC News. Retrieved 2009-07-27, (2009).

14. Arita, M.; Bianchini, F.; Aliberti, J.; Sher, A.; Chiang, N.; Hong, S.; Yang, R.; Petasis, N. A.; Serhan, C. N. J. Expt. Med. 2005, 201, 713-722.

15. Gulzar, S.; Zuber, M. Int. J. Agri. Biol. 2000, 2, 342-343.

16. Mukhopadhyay, T.; Nandi, S.; Ghosh, S. J. Oleo
Sci. 2004, 53, 323-328.

17. Mukhopadhyay, T.; Ghosh, S. J. Oleo Sci. 2007, 56, 399-403.

18. Sharma, S.; Kumar, V.; Sinha, A. K.; Ranjan, J.; Kithsiri, H. M. P.; Venkateshwarlu, G. Fish Physiol. Biochem. 2010, 36, 411-417.

19. Memon, N. N.; Talpur, F. N.; Bhanger, M. I.; Balouch, A. Food Chem. 2011, 126, 405-410.

20. Talwar, P. K.; Jhingran, A. G. Inland fishes of India and adjacent countries 2, Oxford and IBM publishing Co. Pvt. Ltd. New Delhi. 1991, pp 579-591.

21. Kandemir, S.; Polat, N. Turk. J. Fish. Aquat. Sc. 2007, 7, 27-31.

22. Gill, H. S.; Weatherley, A. H. J. Fish Biol. 1984, 25, 491-500.

23. Official methods of analysis of $A O A C$ International, AOAC vol. 1, 16 $6^{\text {th }}$ edn. AOAC International, Arlington (1995).

24. Lathi, E., Filland, Arch. Hydrobiol. 1987, 110, 133-142 ().

25. Folch, J.; Lees, M.; Sloane-Stanley, G. H. J. Biol. Chem. 1957, 226, 497-509.

26. Agren, J.; Mute, P.; Hannmen, O.; Harranen, J.; Pentila, I. Comp. Biochem. Physiol. 1987, 88B, 905-909.

27. Dutta, H.; Das, A. B.; Farkas, T. Comp. Biochem. Physiol. 1985, 81B, 341-347.

28. Yilmaz, Ö.; Konar, V.; Çelik, S. Biyokimya dergisi 1995, 20, 31-42.

29. Yilmaz, Ö.; Konar, V.; Çelik, S. Tr. J. Of Biology 1996, 20, 245-257.

30. Carroll, K. K. Lipids 1986, 21, 731-732.

31. Kinsella, J. E. Pub. Marcel Dekker, Inc. New York 1987, pp 234.

32. Atchison, G. J. J. Fish Res. Board Can. 1975, 
32, 2513-2515.

33. Farkas, T.; Csengeri, I. Lipids 1976, 11, 401407.

34. Farkas, T.; Csengeri, I. Aquaculture 1978, 14, 57-65.
35. Dave, G.; Johanson-sjöbeek, M. L.; Larsson, A.; Lewander, K.; Lidman, U. Comp. Biochem. Physiol. 1976, 53B, 509-515.

36. Castell, J. D.; Sinnhuber, R. O.; Wales, J. H.; Lee, D. J. J. Nutr. 1972, 102, 77-86. 